\title{
New Global Critical Situation: How to Cope With It?
}

\author{
Oleg N. Yanitsky, Ph.D..$^{{ }^{*}}$, Olga A. Basheva, PhD $^{2}$, Nataya S. Mastikova, PhD $^{2}$ \\ ${ }^{I}$ Professor, Chief Researcher, Federal Center of Theoretical and Applied Sociology of the Russian Academy of \\ Sciences. Address: Krzhizhanovskogo Str., 24/35, bld. 5, 117218, Moscow, Russia. \\ ${ }^{2}$ Researcher, Federal Center of Theoretical and Applied Sociology of the Russian Academy of Sciences. \\ Address: Krzhizhanovskogo Str., 24/35, bld. 5, 117218, Moscow, Russia.
}

*Corresponding Author: Oleg N. Yanitsky, Ph.D., Professor, Chief Researcher, Federal Center of Theoretical and Applied Sociology of the Russian Academy of Sciences. Address: Krzhizhanovskogo Str., 24/35, bld. 5, 117218, Moscow, Russia.

\begin{abstract}
Humanity is now encountered with unprecedented global critical situation. The current pandemia and its social, economic, political and other consequences clearly showed that any one-sided approach to global dynamics be it the economic or social one is insufficient. The biological factor came to the forefront. Our main thesis is that the all of us should be both the followers of the directives coming top-down only, and the active participants of the struggle against this new form of world-embracing critical situation. In the final analysis, a man is a social animal. It in turn means that our technologically-oriented world hasn't been prepared to the all-embracing biological attack that has produced the global turmoil and buried all hopes for sustainable development in the foreseeable future.
\end{abstract}

Nowadays, the main issue is the people and their health and not a sustainable development. It means that the modern theorists of globalization have found themselves into the trap of their own mono-disciplinary aspirations and the ideas of an unlimited growth of the world economics. The current critical situation may be to overcome by joint efforts of the scientists, scholars and the civil society activistsonly.

Keywords: biology, civil activists, critical situation, education, future, globalization, isolation, pandemia, science

\section{INTRODUCTION}

We are talking here about the two issues: how to cope with the new global critical situation (Yanitsky, 2014) generated by the corona virus pandemics and to explain to the children, teenagers and their parents what measures against the pandemics are absolutely necessary. We are proceeding from the viewpoint that a majority of the young and adult people has already got a necessary experience of living and working in such earlier unknown situation. Then, we understand that the situation of nearly total isolation from one another is absolutely new for a majority of world population which already accustomed to live and work in entirely other conditions of potential openness and possibility to be in contact with any person at any point across the world.

At the same time, we fully realize that a lot of global issues are still remained unresolved and nearly all of us doesn't sufficiently informed about them. It especially relates to the schoolchildren and teenagers who are concentrated on their own issues and wellbeing. But nowadays the times of a consumer society is abruptly ended. It seems to us that the current pandemics isn't a cause of economic crisis but the all-embracing and all-penetration new living conditions of a global scale related to all of us irrespectively if they are the young or the old, the permanent residents or the migrants, etc. It's not an ordinary crisis but actually new critical situation.

Our main thesis is that the all of us shouldn't be the executors of the directives coming top-down only, but we all have to be the active participants of the struggle against this new form of world-embracing critical situation. In the final analysis, a man is a social animal. This point is related to all ages including the schoolchildren and teenagers.

\section{The MeThodological AND TheORETICAL Foundations OF OUR APPROACH}

Unfortunately, there are no such well-developed foundations yet because the modern humanity is encountered with such all-embracing and threatening challenge for the first time. All existing 
concepts of globalization and its conflicts and crises are based on the one-sided economic concepts of the geopolitical relationships and their possible social outcomes. A biology as a teaching discipline is studied in the schools and universities but as a separate science of various micro processes but not as an integrated part of an interdisciplinary studies of a shaping of the new kind of the biosphere that is the socio-bio-techno-sphere as the certain wholeness.

In many previous researchers like the limits to growth long-term research project (Meadows at al., 1983, 1999), the biological world as such have been considered as one of the limits to global growth or as a mean to produce a sufficient amount of food staffs (the so-called green economy) but practically never as an independent biological force capable to generate a global critical situation. It's rather indicative that humanity is inclined to forget all the negative natural catastrophes including the set of epidemics like the 'Spanish flu' after the WWI.

Our approach to the new situation is as follows. First, current globalization is a very complex process in which environmental, social, technological and microbiological structures are tightly interdependent.

Second, the current globalization presents not a combination of the above structures and processes but a certain wholeness integrated by the metabolic processes. These processes have a variety of forms and results ranging from mutual enhancement till mutual annihilation.

Third, these metabolic processes aren't simply integrates these qualitative different processes and structures but permanently transform each other. Four, in turn it means that there is no the biosphere as such (in a commonly accepted meaning) but it already has step by step been replaced by the abovementioned socio-bio-technical sphere (hereafter the global SBT-system).

Five, this global SBT-system is in the process of permanent shaping and transformation under the influence of human and natural activity. In contrast to the biosphere a turnover of a matter and energy in the global SBT-system has no strict regularities of these processes.

Therefore, sixth, it's still unclear is that SBT-system presents a certain systemic wholeness, or it is a permanently changing conglomerate of qualitatively different processes and structures that compete each other? To our mind, the SBT-system is a systemic wholeness but very unstable one due to the above various metabolic processes and structures.

Seventh, these and many other theoretical novelties should be accessible and understandable to the teachers, tutors and to ordinary people in the form of uninterrupted upgrading by means of permanent seminars, colloquiums, distant or in the auditory.

Eighth, it means that a communication between the teachers and the collectives which are capable to carry out such interdisciplinary studies of the global SBT-system and its nonlinear dynamics had to be maintained permanently.

Ninth, the matter is: Does the scientists and scholars are already prepared to such collaboration? Our answer will be definitely 'not', the both sides seem not ready. Is there a way out? We are convinced that 'yes' if they both doesn't want to become the outsiders or even victims of an unintended global calamity.

Tenth, such bilateral collaboration of the scholars, scientists, teachers and civil society activists requires the substantial changes in the institutional structure of a science and education as the social institutions. This integrated institutional structure should decisively to overcome the barriers between the monodisciplinary structures of modern science established by the Enlighteners even in XVI-XVII centuries.

Eleventh, one of the key issues of the interdisciplinary researchers and teaching is an issue of time duration of particular processes and the metabolic reactions. It's one of the most difficult issues of the analysis of such global SBT-systems. In comparison of military sciences including the small and great warship campaigns in which the time of operations plays a key role in the sociology of the large systems and in other humanities the time usually has three dimensions only: the past, present and future.

Twelfth, on the contrary, our everyday life irrespectively is it movable or relatively stable has many specific dimensions of time and the tempo-rhythms, and everyone see all of them necessary. But it's a 
mistake to think that the regularity inherent to our everyday life is directly applicable to the shaping of global SBT-system.

Thirteenth, we didn't callall teachers, scholars and scientists to become such theorists as Teilhard de Shardin or Vladimir Vernadsky had been. But we all obliged to be capable to think simultaneously locally and globally, and to keep in mind that the global SBT-system and its components has various tempo-rhythms of their activity, metabolic processes and structural transformations.

Fourteenth, the current pandemia of the corona virus and its multisided consequences clearly showed that our world is tightly interdepended, and thus we, scientists, scholars and teachers and the grassroots activists should think complexly and teach the children and adults to do the same. The Greens are right: we should think globally and to act simultaneously locally and globally.

In sum, any educational process should take into account a positive-negative dialectics of the globalization processes. The teachers and their pupils of any age shouldn't be only the passive participants of that process but should be prepared to become the active fighters with the negative sides and after-effects of the above processes.

\section{What ARE The Realities ANd Prospects of the NeAR AND Remote Future?}

To begin with, initially one of us had stated that the information-and-communication networks have the all-embracing and all-penetrating character. And up to now we've seen that the results of the contacts of the individuals and their groups have the same character.

But recently the global situation has changed dramatically. Instead of a numerous and multisided global contacts we've turned toward a few ones; from the all-embracing social and spatial mobility toward a prescribed number of minimum one-to-one contacts; from global mobility toward nearly total isolation; from the endless business communication toward a quite limited number of them and so on and so forth. In sum, we've lived in the world of permanently growing number of contacts, whereas now the population of the majority of the countries is living in a nearly total isolation from one another.

Such conclusion made by the study of the foreign media has shown that a total isolation of the individuals and their groups, at least up to now is the only one efficient measure of a restriction of further spread of the pandemia across the world. It in particular follows that the information-andcommunication and one-to-one networks have the same origin i.e. they are both have non-linear and sometimes ad hoc character.

Under the conditions of total self-isolation coupled with an unknown future, the decay of habitual modes of production and social communication, and the attempts of the state and global authorities to cope with the all-embracing critical situation by means of various prohibitions - all that generates the people's embarrassment and fear in front of unknown future. If we still will survive, what should we do: to restore the existed structures and networks or to construct the entirely new ones?

\section{The Migrants AND COMMUTERS}

The first group is the migrants came to the EU, Russia and other countries from abroad. It's the most risky and sometimes dangerous category of the migrants because they demand at once all facilities that urban residents of well-developed countries are already have (a shelter, work, medical aid, the schools and kindergartens for their children, to master the national language, etc.). In Russia after the decay of the Soviet Union we have been already prepared to such influx but in the US and the EU the immigrants is a serious economic, social and political issues.

Due to the emerging mass unemployment in any critical case a tough concurrence between the residents and newcomers is very possible. Looking at the current migration crisis in the EUwe may conclude that the European Union hasn't been prepared to such mass invasion of the migrants the majority of them demand a work, shelter, schools for their children, and so on and so forth. In addition, the majority of them are the carriers of entirely different culture and religious in comparison of the EU residents. Actually, as one of us has seen in the Norway the immigrants from African countries are living separately. May by under current critical conditions it's a best way to separate the healthy local residents from the possible carriers of corona virus pandemics and other many other unknown in the Europe diseases. Besides, the dealers of the shadow economy often have used the illegal migrants as an unofficial working power without paying any taxes. 
The commuters are a quite another category of the migrants. They are the permanent residents who are able to shift to their country-house(datcha), or to their relatives in a village, or to rent such country-house for several months, etc. The mayor of Moscow city has recommended to the city inhabitants to spend several months in the country-side. It's a good recommendation if there is a possibility to be plug in the global network but with one exception. The matter is that their apartments or private houses have to be well-protected from the robbers.

\section{Does the Volunteering in Such Critical Situation Possible?}

For the first glance, it seems absolutely not for the reason of so many regulations and restrictions.

But let us look back in Russian history of XX century and even before. A human togetherness and cohabitation had been the inseparable features of Russian history especially particularly in the times of the struggle for its independence in the run of any aggressive invasions as well as in the times of civil wars and post-war rehabilitation.

The common key reason of such volunteering activity is the lack of the labor power especially in the destroyed cities and villages and junior personal in the hospitals and other places of people's rehabilitation.

The matter is that such human qualities as mutual help and support for the young and the old have to be inculcated from the childhood (Stepansky, 1980).Let's refer to the experience of Oleg Yanitsky' family. Both of his grandfather and grandmother have been the volunteers. The grandmother saved the Jews from the Black Hundred and other Russian extremist's organizations before the WWI (Laquer, 1993).His grandfather being the monarchist nevertheless had rendered financial and other help to the imprisoned and their families. Their daughter Vera Schmidt had worked with the homeless children and collaborated in that matter with prof. Zigmunt Freud.

Recently, almost immediately after the people found out about the impending threat the independent volunteers in large Russian cities (in particular, in Moscow and St. Petersburg) began to organize the first communities in messengers (in particular, by means of the Telegram messenger) and by other social networks to discuss possible actions, primarily related to render help to older people who are at a first group of risk. Further, their initiatives went offline. Volunteers mobilized by the government agencies and pro-government organizations also quickly mobilized (Blumer, 1958; Along..., 2020; Corona virus epidemic..., 2020).

It's rather indicative that after the beginning of the current pandemics the ordinary people in the EU and Russia sharply changed their consumerist mode of living shifting to the more modest way of life and began to render help to their neighbors and to those who has been needed in an immediate assistance and financial support.

\section{CONCLUSION AND DISCUSSION}

Nowadays, humanity suddenly entered into a highly risky society. Its specificity is in the real allembracing losses of people, destruction of businesses, communications and logistics, etc. Under these critical conditions it appears that the modern theorists of the globalization process are still practice one-sided approach to it and haven't still seen its dialectical and interdisciplinary character. Technology-oriented world hasn't been prepared to the all-embracing biological attack that has produced the global turmoil and buried all hopes for sustainable development.

We don't think that the current developments will inevitably lead us to global collapse but we convinced that the losses of such unintended consequences generated by joint economic and biological crises will be very serious, may be more serious than the human losses and damages of the WWII. Anyhow, a mutual isolation isn't a way out, because the restoration of the destroyed of thousands productive and human networks are impossible, and the construction of the new ones requires financial, natural and human resources, and will take a long time.

Nowadays, the main issue is the people and their health and not a sustainable development. It means that some theorists of globalization have found themselves into the trap of their own mono- 
disciplinary aspirations and the ideas of an unlimited growth of the world economics. These theorists and politicians didn't take into account that humanity isn't only the machinery for a permanent economic growth but a very complicated global SBT-system that has its own regularities of development and limits to growth, and its biological regularities as important as the global market ones. The lessons of the epidemic of the Spanish flu haven't been taken into account. But keeping in mind the technological innovations we foresee that global market of biological weapons came to the forefront.

We think that there are two ways out of such critical situation. The former is to cancel all possible contacts between the people in order to diminish the spread of the pandemics. It's very efficient but short-time administrative method of the struggle with the pandemics. If such isolation will continue for a long while there is a high probability to enter into a long-term economic and social crisisor even into the all-embracing global chaos.

The latter has at least two steps. The first is to combine such isolation measures in a short-term perspective with the intensive development of combination of the interdisciplinary researchers with a production of individual measures of defense from the corona virus infection. The second one has a fundamental character: humanity has to understand that he is living in the very complex world in which a biological transformations and threats are as important as economic and social ones.

Under the pressure of the one-sided 'isolation measures' almost in the majority of countries a habitual living environment with its rules of games has sharply shrunk. If such all-embracing 'isolation measures' will continue for a long time (a couple of months or even years), the principles of market economy and its social norms as a 'consumerist' way of life could be seriously wounded.

A majority of social institutions aren't able to work in a mobilization regime permanently. But the emergence of illegal labor market and violations of numerous restrictive measures clearly show that these measures couldn't live for a long time.

Recently, the educational process should take into account a positive-negative dialectics of current globalization. The teachers and their pupils of any age shouldn't be only the passive participants of that process but should be prepared to become the active fighters with the negative sides and aftereffects of the above pandemics.

All said above means that any educational process should pay an equal attention to 'normal' and critical processes and structures of our times. We have to realize that the constructive and destructive processes of the global SBT-system evolution are going hand in hand. And in both cases the volunteers as necessary as the professionals.

Funding: this article is funded by the Russian Scientific Fund, grant No 19-78-10052, the project 'Emergency volunteering as a reply to the natural and technological challenges in Russia'.

\section{REFERENCES}

[1] Along with work, fear of the law is lost. 2020. Izvestiya, Moscow. Available at: https://iz.ru/991183/ivanpetrov/zatishe-pered-burei-kak-covid-2019-povliiaet-na-prestupnost

[2] Blumer H. 1958.Race Prejudice as a Sense of Group Position. Pacific Sociological Review, vol. 1, no. 1, pp. 3-5.

[3] Coronavirus epidemic through the eyes of a Moscow taxi driver from Kyrgyzstan. 2020. DW, Moscow. Available at: https://bit.ly/2wPQjPk

[4] Laquer W. 1993.Black Hundred: The Rise of the Extreme Right in Russia. N.Y: Harper Collins Publishers. $318 \mathrm{pp}$.

[5] Meadows D.L. and Meadows D. H., eds. 1973.Toward Global Equilibrium. Cambridge, Mass.: WrightAllen Press.

[6] Meadows D.H., Meadows D. 1., Randers J.W. 1989.The Limits to Growth.A Report for the Club of Rome's Project on the Predicament of Mankind. 2nd ed. N.Y.: Universe Books.

[7] Stepanskyi A. 1982. Civic Organizations on the Edge of XIX-XX Centuries [obshchestvennye organizatsiinarubezhe XIX-XX vekov]. Moskow.162 pp.

[8] Schmidt V. 1924.PsychanalytischeErziehung in Sowietrussland. Leipzig, Zurich, Wien: Internationaler PsychanalytischeVerlag. 75 S. 
[9] Yanitsky O. 2012. The Family Chronicle.1852-2002.2nd edition, Moscow: TAUS. 271 pp.

[10] Yanitsky O. 2014. Sociology of Critical Areas. Open Journal of Social Science Research. Vol.2 (3): 112118. Available at: http://manuscript.sciknow.org/uploads/ojssr/pub/ojssr_140963345.pdf

Citation: Oleg N. Yanitsky, Ph.D., et.al. "New Global Critical Situation: How to Cope With It?" International Journal of Research in Sociology and Anthropology (IJRSA), vol 6, no. 1, 2020, pp. 31-36. doi: http://dx.doi.org/10.20431/2454-8677.0601004.

Copyright: (C) 2020 Authors. This is an open-access article distributed under the terms of the Creative Commons Attribution License, which permits unrestricted use, distribution, and reproduction in any medium, provided the original author and source are credited. 